EM

\title{
CONFLITOS DE USO DA TERRA NA ZONA DE AMORTECIMENTO DO PARQUE ESTADUAL ALTAMIRO DE MOURA PACHECO - GOIÁS
}

\section{LAND USE CONFLICTS IN THE BUFFER ZONE OF ALTAMIRO DE MOURA PACHECO STATE PARK - GOIÁS}

\author{
Jaqueline Gomes BATISTA ${ }^{1}$ \\ Karla Maria Silva de FARIA ${ }^{2}$ \\ Luciana Gonçalves TIBIRIÇÁ ${ }^{3}$
}

\begin{abstract}
Resumo: O Parque Estadual Altamiro de Moura Pacheco (PEAMP) está inserido no Bioma Cerrado e tem grande relevância para a promoção da conservação do Cerrado goiano e para proteção do reservatório do Ribeirão João Leite. $\mathrm{O}$ trabalho teve o objetivo de avaliar os conflitos existentes na Zona de Amortecimento (ZA) e nas Áreas de Preservação Permanente (APPs) de seus cursos hídricos, nascentes e reservatório. Os procedimentos metodológicos envolveram a elaboração de mapas de uso da terra utilizando imagens Landsat de 2002 e 2018, além do processamento para avaliação dos conflitos em APPs de cursos hídricos e para a ZA do PEAMP, conforme seu zoneamento. Os resultados indicaram predominância de pastagem na área, além da existência significativa de conflitos nas diversas zonas. Nas APPs de cursos hídricos predominavam as áreas conflitantes em 2002, mas em 2018 o predomínio foi das áreas de vegetação, e aumentou consideravelmente a área ocupada por água, devido à implantação do reservatório. Destaca-se que, embora tenham sido constatados conflitos de uso na ZA do PEAMP, foi observado um aumento significativo das áreas de vegetação no ano de 2018, que permite concluir que a gestão na região está sendo eficaz na promoção da conservação e recuperação de determinadas áreas.
\end{abstract}

Palavras-Chave: Conflitos de uso; Unidades de Conservação; Zona de Amortecimento; APPs.

\begin{abstract}
The Altamiro de Moura Pacheco State Park (PEAMP) is into on the Cerrado biome and has a great relevance to the promotion to the Cerrado goiano conservation, and also to the protection João Leite River reservoir. This paper objective was to evaluate the existing conflicts in the buffer zone (BZ) and in the Permanent Preservation Areas (PPAs), their water resources, springs and reservoir. The methodological procedures involved a land use maps elaboration, using Landsat images from 2002 and 2018, in addition to processing for assessing conflicts in water resources PPAs and for the $\mathrm{BZ}$ of PEAMP, according to their zoning. The results indicated a pasture area predominance, and significant conflict presence in diverse zones. In the water resources PPAs was predominated the conflicting areas in 2002, but in 2018 the predominance was vegetation areas, and considerably increased the area occupied by water, due the reservoir implantation. It is noteworthy that, although conflicts of use were found in the BZ of PEAMP, a significant increase was observed in the vegetation areas in the year 2018, which allows us to conclude that region's management are turning effective in the promoting preservation and also recovery of specific areas.
\end{abstract}

Keywords: Conflicts of use; Conservation Parks; Buffer Zone; PPAs.

\footnotetext{
${ }^{1}$ Cientista Ambiental. Mestranda do Programa de Pós-Graduação em Geografia da Universidade Federal de Goiás. E-mail: jaquelinegmsb@gmail.com

${ }^{2}$ Doutora em Geografia pelo Programa de Pós-Graduação em Geografia da Universidade Federal de Goiás. Professora do Instituto de Estudos Socioambientais - UFG. E-mail: karla_faria@ufg.br

${ }^{3}$ Doutora em Geografia pelo Programa de Pós-Graduação em Geografia da Universidade Federal de Goiás. Professora do Instituto de Estudos Socioambientais - UFG. E-mail: luciana.tibirica@gmail.com
} 
EM

\section{Introdução}

O Cerrado é o segundo maior bioma da América do Sul, ocupando, segundo o IBGE (2004), uma área de $2.036 .448 \mathrm{~km}^{2}$, o que equivale a aproximadamente $24 \%$ do território brasileiro. Além de sua vasta extensão territorial, esse bioma também tem grande relevância, por ser habitat para grande diversidade de espécies da fauna e flora e por atuar como "berço das águas", abrigando nascentes de importantes bacias hidrográficas, como a Amazônica/Tocantins, São Francisco e Prata (MMA, 2018).

Mesmo com sua grande relevância ecológica, o processo de ocupação do Cerrado tem sido intensivo nas últimas cinco décadas, impulsionado por políticas públicas que induzem à modernização, que promove alterações no modo de vida e de produção locais, gerando, consequentemente, grandes transformações no cenário regional (CHAVEIRO e BARREIRA, 2010). Aliado às poucas medidas de proteção legal, esse bioma tem sofrido uma redução significativa em seu território, chegando a perder uma área de 119.765,83 km² entre 2005 e 2018, segundo o portal TerraBrasilis (2019), o que resulta numa crescente ameaça a diversas espécies e no comprometimento da qualidade ambiental de suas bacias hidrográficas.

Inserido neste contexto está o Parque Estadual Altamiro de Moura Pacheco (PEAMP), uma Unidade de Conservação (UC) de Proteção Integral com grande relevância para a promoção da conservação do Cerrado goiano. Administrada pelo governo de Goiás, criada em 1992, tem como objetivo principal proteger o maior remanescente de Mata Seca na região central do Estado e também o reservatório do Ribeirão João Leite, que é responsável pelo abastecimento hídrico de algumas das cidades que compõem a Região Metropolitana de Goiânia (SEMAD, 2015).

O PEAMP está inserido na Bacia Hidrográfica do Ribeirão João Leite (BHRJL), que também abrange o local onde se situa a Área de Proteção Ambiental do João Leite (APAJoL), UC de uso sustentável que foi criada em 2002 com os seguintes objetivos principais: proteger os recursos hídricos de tal bacia, incluindo o reservatório do João Leite; orientar e disciplinar as atividades econômicas a serem desenvolvidas na área, para melhorar a qualidade de vida da população local, além de incentivar a preservação ambiental; proteger os remanescentes do bioma Cerrado; disciplinar o turismo ecológico e fomentar as práticas de educação ambiental na região (STCP e SEMAD, 2019).

Os objetivos vinculados à criação da APAJoL englobam, portanto, os aspectos ambientais e sociais mais relevantes para a área, levando em consideração tanto os atributos socioeconômicos e culturais, quanto as funções ecológicas que visam garantir o papel da UC na sociedade. Dessa forma, e de modo a garantir a conectividade entre UCs e remanescentes vegetais do entorno, esses aspectos foram levados em consideração pela gestão do PEAMP, induzindo à escolha da APAJoL como sua Zona de Amortecimento (ZA), a partir da elaboração de seu Plano de Manejo (PM).

Segundo Brasil (2000), a ZA é "o entorno de uma unidade de conservação, onde as atividades humanas estão sujeitas a normas e restrições específicas, com o propósito de minimizar os impactos negativos sobre a unidade". As responsabilidades de delimitação e ordenamento de uma ZA são da entidade gestora da UC a qual está vinculada, e é fundamental que se faça o manejo adequado dessas áreas, pois há indicativos, como o feito por Primack e Rodrigues (2001), de que se o entorno de um parque for degradado, consequentemente, a diversidade biológica e qualidade ambiental de seu interior também serão afetadas.

Diante dos fatores expostos, o presente trabalho surgiu com o objetivo de analisar os conflitos de uso existentes na ZA do PEAMP, com base em seu PM e em conceitos e critérios legais. A partir do levantamento dos tipos de uso e cobertura da terra existentes nessa área, e 
EM

da delimitação de suas Áreas de Preservação Permanente (APPs) para corpos hídricos, realizou-se uma análise integrada da atual situação da ZA e de suas APPs de canais de drenagem, nascentes e do reservatório do Ribeirão João Leite, no intuito de verificar se os usos nessas áreas são conflitantes com as propostas da UC em questão e com a legislação vigente, e se houveram avanços ou retrocessos nesse quesito entre os anos de 2002 e 2018.

\section{O histórico das Unidades de Conservação e os conflitos socioambientais correlacionados}

Segundo Dias e Pereira (2010), o interesse em preservar determinadas áreas no Brasil existe desde o século XVIII, onde o naturalista José Bonifácio de Andrada e Silva criticava a destruição ambiental e sugeria as primeiras iniciativas para manutenção das florestas brasileiras, incentivando o conhecimento científico sobre elas. Outra visão apontada pelos autores foi a de André Rebouças, em 1876, que lançou as primeiras propostas de criação de parques nacionais no Brasil, a fim de valorizar os aspectos estéticos vinculados aos recursos naturais, e incentivar a contemplação dessas áreas, como forma de agregar valor econômico a elas. Tais visões tinham interesses puramente econômicos e políticos, pois a riqueza de recursos naturais no território brasileiro era considerada como um trunfo para o futuro progresso do país.

Nesse sentido, Diegues (2008) aponta que os preceitos legais e teóricos para a conservação de grandes áreas naturais somente foram definidos no século XIX, a partir da criação do Parque Nacional de Yellowstone, em 1872, como o primeiro grande exemplo de preservação de extensas áreas naturais, o que refletia principalmente o interesse da sociedade em seu próprio benefício. Esse foi o modelo que inspirou a ideia de André Rebouças, em 1876, e que foi utilizado como base pelo governo do Brasil em 1937, na instituição de seu primeiro parque, o Parque Nacional do Itatiaia, que tinha como principal objetivo proteger uma área natural com grande beleza cênica, para usufruto de visitantes.

O modelo tradicional adotado pelo Brasil, portanto, levava em consideração principalmente os aspectos paisagísticos de determinadas regiões, vinculando-as à ideia de monumentos públicos naturais com grande valor estético e científico, e de porções preservadas da natureza, em meio a áreas já antropizadas, na tentativa de reproduzir a ideia do paraíso perdido, (DIEGUES, 2008; DIAS e PEREIRA, 2010), o que fragilizava a gestão e o manejo dessas áreas. Essa concepção, entretanto, se alterou ao longo do tempo e, em 2000, com a criação do Sistema Nacional de Unidades de Conservação (SNUC), um conceito oficial para UCs foi estipulado, juntamente com diretrizes mais consolidadas para sua gestão e manejo, com variação de acordo com cada categoria.

Conforme Brasil (2000), o SNUC tem diversos objetivos, incluindo o de proteger paisagens de notável beleza cênica e de promover o desenvolvimento sustentável a partir do uso dos recursos naturais, típicos do modelo tradicional, ao mesmo tempo que envolve diversos outros objetivos, como a contribuição para manutenção da diversidade biológica e dos recursos genéticos, preservação e restauração de ecossistemas. Tais objetivos asseguram maior funcionalidade às UCs, que passaram a ser consideradas áreas com características naturais relevantes, legalmente instituídas pelo Poder Público, cujos princípios são de conservar áreas previamente delimitadas, sob regime especial de administração, ao qual se aplicam medidas adequadas de proteção.

As UCs se dividem em dois grupos, de acordo com o SNUC, podendo ser de proteção integral, englobando as categorias Estação Ecológica; Reserva Biológica; Parque Nacional; Monumento Natural e Refúgio de Vida Silvestre, ou de uso sustentável, composta pelas categorias Área de Proteção Ambiental; Área de Relevante Interesse Ecológico; Floresta 
EM

Nacional; Reserva Extrativista; Reserva de Fauna; Reserva de Desenvolvimento Sustentável e Reserva Particular do Patrimônio Natural (BRASIL, 2000).

Diegues (2008) aponta que, a princípio, as UCs no Brasil não levavam em consideração as populações tradicionais habitantes nas áreas destinadas à proteção, nem mesmo as experiências de manejo desses povos, obrigando-os a se retirarem, o que gerou diversos conflitos. Esse problema perdurou por certo período, sem ser discutido, até que em 1962 começou a ser debatido, durante o Terceiro Congresso Mundial de Parques Nacionais, ocorrido em Bali (Indonésia). Na ocasião foi abordada a questão da interação existente entre as áreas protegidas e o desenvolvimento socioeconômico vinculado a elas. Para Diegues (2019), o principal motivador desse tipo de conflito é o poder associado ao conhecimento científico, utilizados pelo governo para justificar muitas de suas intervenções em áreas frágeis tanto no campo social quanto ambientalmente. Todavia, tal situação tem mudado lentamente e o conhecimento tradicional e a etnociência têm conquistado mais espaço.

Além dos atritos existentes com populações tradicionais, as UCs também estão passíveis ao surgimento de outros conflitos, que tendem a ser cada vez mais recorrentes, pois comumente envolvem áreas ricas em recursos naturais, que estão em crescente demanda, e são importantes alvos de diversos interesses socioeconômicos. Segundo Gomes, Carmo e Santos (2004, p. 24), "geralmente, os conflitos relacionados aos recursos naturais estão nas terras que os contêm e, portanto, entre os grupos humanos que reivindicam essas terras como seu território de moradia e vivência, tendo dimensões políticas, sociais e jurídicas".

No entorno do PEAMP, por exemplo, há intensa expansão urbana e agropecuária, devido principalmente à proximidade com as cidades de Goiânia e Anápolis, que constituem um importante polo econômico da região Centro-Oeste do país. Essa condição dificulta a função de preservação da área, como apontam estudos, como o realizado por Coelho (2011), que apresenta os diversos impactos ambientais existentes na BHRJL. Além dos fatores citados acima, outra questão que intensifica a possibilidade da existência de conflitos no PEAMP e em seu entorno é o fato de sua ZA corresponder a uma APA, que é, de acordo com Brasil (2000):

Uma área em geral extensa, com certo grau de ocupação humana, dotada de atributos abióticos, bióticos, estéticos ou culturais especialmente importantes para a qualidade de vida e o bem-estar das populações humanas, e tem como objetivos básicos proteger a diversidade biológica, disciplinar o processo de ocupação e assegurar a sustentabilidade do uso dos recursos naturais.

As APAs têm parte significativa de seu território inserida dentro de propriedades privadas, o que coloca suas paisagens sobre maiores riscos de alterações e degradação. Isso implica na demanda por mais atenção quanto a essas áreas, já que o alto grau de interferência antrópica sobre os recursos naturais, aliado à ausência de planejamento eficaz, pode impedir que esse tipo de UC cumpra com sua função de proteção. Nesse sentido, é criado então um paradoxo, pois, considerando o meio ambiente como um bem coletivo, onde os atores disputam os seus interesses, a proteção ambiental pode ser uma solução para um determinado conflito, ao mesmo tempo que pode também derivar novos conflitos (GOMES; CARMO; SANTOS, 2004).

\section{Caracterização da área de estudo}

O PEAMP foi criado pela Lei ${ }^{\circ} 11.878$ de 30 de dezembro de 1992 e tem como objetivo não apenas proteger o maior remanescente de Mata Seca da região central de Goiás e 
EM

o reservatório do Ribeirão João Leite, como mencionado anteriormente, mas também abrigar sítios arqueológicos. Segundo SEMARH e ITCO (2008), na última pesquisa arqueológica realizada no PEAMP foram localizados 9 sítios, dos quais 6 foram considerados préhistóricos, 2 históricos e 1 duvidoso, após nova análise.

Os sítios pré-históricos, de um modo geral, foram ocupados entre os séculos XI e XIV, por grupos de ceramistas que praticavam agricultura ainda incipiente, onde predominava o cultivo de algodão, milho e tubérculos, e os principais materiais encontrados nessas áreas foram fragmentos de recipientes de cerâmica com características mais simples, aparentemente com finalidades mais utilitárias, a exemplo de pratos, panelas e jarros. Compõem esse grupo os sítios Bananeira, Macaúba e Pau d'Óleo, localizados no município de Goianápolis, além do Corrente, Lobeira e Cana Brava, situados no município de Nerópolis (SEMARH e ITCO, 2008).

Os sítios históricos datam a partir da segunda metade do século XIX e primeira metade do século XX, sendo representados por antigas sedes de fazendas, cujos principais materiais encontrados foram peças e fragmentos de ossos, cerâmica, louça, vidro, metal e material lítico. São representados pelo Sítio Casa Grande, atual sede administrativa do PEAMP, e pelo Sítio Goiabeira, ambos situados no município de Goianápolis e localizados muito próximos aos limites do Parque (SEMARH e ITCO, 2008).

Conforme citado anteriormente, a ZA do PEAMP corresponde à APAJoL, que foi criada pelo Decreto Estadual $\mathrm{n}^{\circ} 5.704$, de 27 de dezembro de 2002, apresenta 713,57 km² e abrange os municípios de Anápolis, Campo Limpo de Goiás, Goianápolis, Goiânia, Nerópolis, Ouro Verde de Goiás e Terezópolis de Goiás (Figura 1).

Figura 1 - Localização da área de estudo.

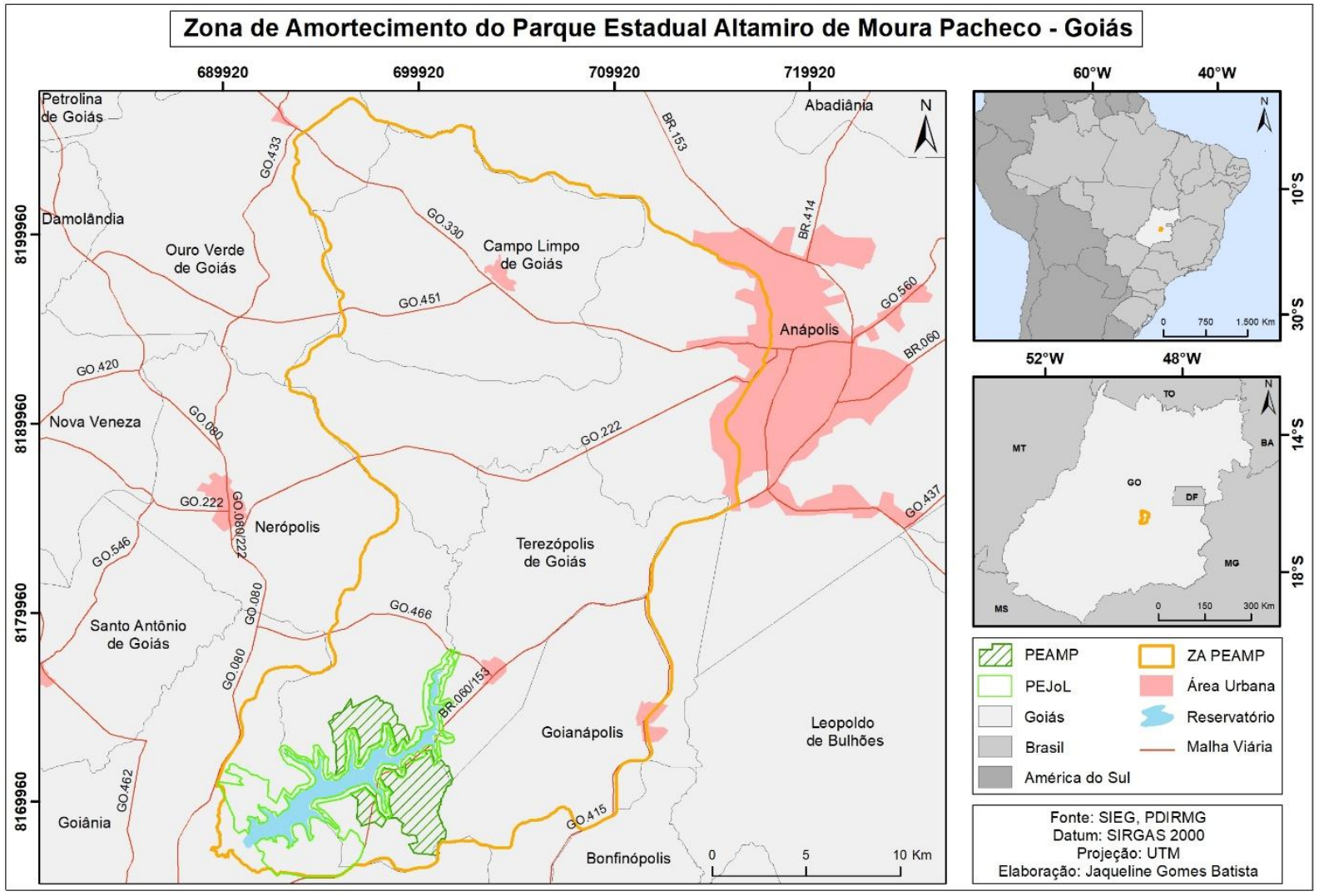

Fonte: Autoral. 
EM

Convém ser destacado que, inicialmente, o PEAMP possuía área de 3.183 hectares, mas em maio de 1993 sua área protegida foi reduzida para 2.132 hectares, devido à futura implantação do Reservatório do Ribeirão João Leite. Posteriormente, parte da área que fora excluída para instalação do reservatório foi transformada no Parque Estadual do João Leite (PEJoL), criado pela Lei Estadual $\mathrm{n}^{\circ}$ 18.462, de 09 de maio de 2014 (SEMAD, 2018), totalizando assim em 4.964 hectares de áreas protegidas integralmente por essas duas UC's.

Quanto às características do meio físico, praticamente todo o território da ZA do PEAMP está sobre Superfícies Regionais de Aplainamento, mas há também, em pequenos trechos, à Noroeste da ZA, Zonas de Erosão Recuante (LATRUBESSE e CARVALHO, 2006). A hipsometria da ZA tem uma variação expressiva e as zonas mais rebaixadas estão na parte central, onde está o canal principal da drenagem e também o reservatório do João Leite, com altimetria variando entre 712 e $874 \mathrm{~m}$, enquanto a porção correspondente às maiores altitudes é mais restrita às extremidades da bacia, variando entre 953 e $1144 \mathrm{~m}$.

O relevo é, predominantemente, suave ondulado a ondulado, apresentando áreas planas nas partes centrais, e regiões fortemente onduladas e montanhosas em porções mais restritas, principalmente nas extremidades da ZA. Há cinco classes de solo na área de estudo, predominando os Argissolos Vermelho Amarelo eutróficos, nas porções onde o relevo é mais movimentado, e os Latossolos Vermelho ácricos, nas áreas com declividade plana a suave ondulada. Áreas de Cambissolos Háplicos Tb distróficos e eutróficos e Plintossolos Pétricos Concrecionários são restritas a pequenas porções, onde o relevo varia de fortemente ondulado a fortemente montanhoso. Os Gleissolos são encontrados em dois pequenos trechos, apenas na região central, associados a canais de drenagem, e ao noroeste da bacia há uma mancha expressiva de Argissolos Vermelho eutróficos, correlacionados à declividade ondulada a fortemente montanhosa.

\section{Procedimentos metodológicos}

O estudo se dividiu em cinco etapas. Primeiramente foram realizados levantamentos bibliográficos, referentes tanto à área de estudo quanto ao tema trabalhado, e esse passo foi recorrente ao longo do desenvolvimento de toda a pesquisa, tendo como fontes os acervos da Universidade Federal de Goiás, Sistema Estadual de Geoinformação de Goiás, pesquisas em sites de busca de periódicos acadêmicos, dentre outras.

A segunda etapa envolveu o processo de construção da base de dados, selecionando imagens de junho, correspondentes ao período de seca na região, dos anos de 2002 e 2018, ambas provenientes do satélite Landsat, obtidas gratuitamente pelo Instituto Nacional de Pesquisas Espaciais (INPE, 2018). Para 2002 a imagem utilizada foi do satélite Landsat 7 e para 2018 imagem do Landsat 8, sendo a primeira pertencente ao sensor ETM+, e a segunda ao sensor OLI, cujas resoluções espaciais são muito favoráveis à aplicação das técnicas de sensoriamento remoto e geoprocessamento, fundamentais para o diagnóstico ambiental e a classificação do uso da terra.

A terceira etapa refere-se ao tratamento prévio dos dados e à elaboração dos mapas, cujos procedimentos de sensoriamento remoto, para classificação do uso da terra, foram realizados no SPRING, software livre, com as bandas RGB 5, 4, 3 para a imagem do Landsat 7, e 6, 5, 4 para a imagem do Landsat 8, correspondentes às cores naturais simuladas, sendo aplicado o contraste às composições coloridas.

O método utilizado para classificar o uso da terra foi de classificação supervisionada, por meio da Máxima Verossimilhança (Maxver), que é o mais utilizado para obtenção de classes informacionais a partir de imagens de sensores remotos (RIBEIRO; BAPTISTA E 
EM

QUESTÃO

V.13 N. $03 \bullet 2020$

pág. 51-70

BIAS, 2007). Foram selecionadas nas imagens áreas modelos dos pixels representativos para cada classe de uso da terra, permitindo que o software avaliasse a possibilidade de um determinado pixel pertencer a uma categoria, classificando-o para aquela com maior probabilidade de associação. As classes geradas foram de água, vegetação, solo exposto (onde se incluiu as atividades de mineração), área urbana, agricultura e pastagem. As confusões geradas pelo classificador para as classes de agricultura, pastagem e área urbana foram corrigidas manualmente por inspeção visual no software ArcGIS.

A quarta etapa envolveu a construção dos mapas de conflitos de uso da terra para APPs de nascentes, canais de drenagem e do reservatório do Ribeirão João Leite para os anos de 2002 e 2018, que demandou, primeiramente, o refinamento da rede de drenagem, com base nos dados elaborados pela equipe de mapeamento do Plano de Desenvolvimento Integrado da Região Metropolitana de Goiânia e da SRTM (Missão Topográfica Radar Shuttle). A ZA do PEAMP tem seus limites coincidentes com 93\% da BHRJL, que de acordo com SEMARH e ITCO (2007), apresenta uma área de 764,75 km², curso principal com cerca de $135 \mathrm{~km}$ de extensão e nascentes aflorando no limite Norte da bacia hidrográfica, próximo ao município de Ouro Verde de Goiás, sendo o Córrego das Pedras e o Ribeirão Jurubatuba os principais formadores do Ribeirão João Leite (figura 2).

Figura 2 - Rede hidrográfica da área de estudo.

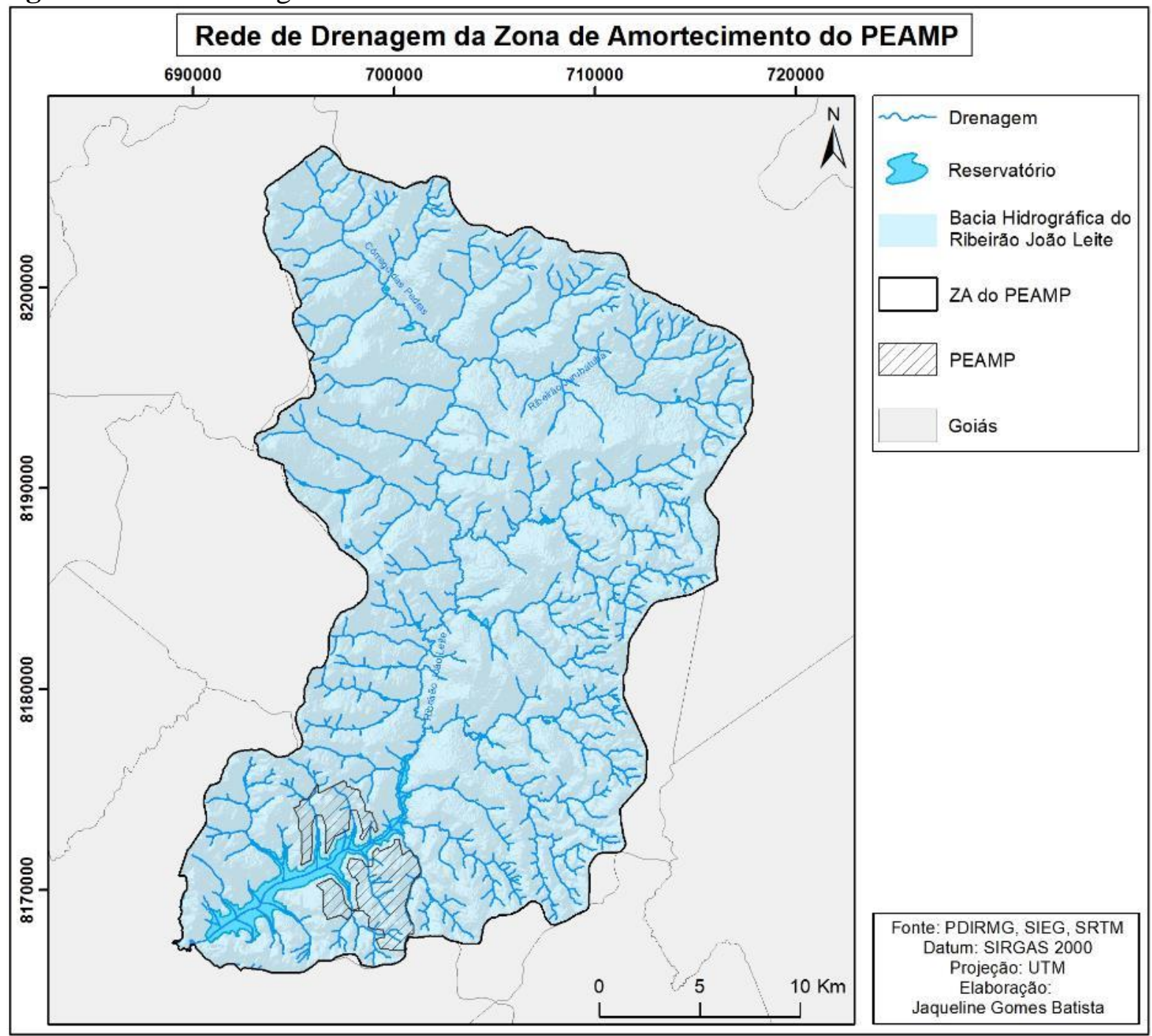

Fonte: Autoral. 
EM

Após a obtenção da drenagem refinada foram gerados os buffers que delimitavam as seguintes distâncias para as APPs: 50 m para nascentes; 50 m para o Ribeirão João Leite e 30 $\mathrm{m}$ para os demais canais de drenagem. Estes limites obedecem ao estabelecido no Plano de Manejo do PEAMP e, como não foi possível acessar a licença do reservatório, adotou-se a faixa máxima de $100 \mathrm{~m}$, proposta pelo art. $5^{\circ}$ da Lei $\mathrm{n}^{\circ} 12.727$ (BRASIL, 2012), como APP para o reservatório de água artificial, destinado ao abastecimento público e situado em área rural. Concluídos esses procedimentos, foi realizada a intersecção entre os dados obtidos pela classificação do uso e cobertura da terra na ZA do PEAMP para os anos de 2002 e 2018 e os buffers elaborados para as APPs inseridas na ZA, possibilitando a geração dos mapas de conflitos de uso e cobertura da terra em APPs de cursos de água, nascentes e reservatório, adotando-se como únicas classes não conflitantes com a função ecológica dessas áreas a vegetação e a água.

De acordo com o MMA (2015), os problemas existentes dentro de UCs, caracterizados como pressões ou ameaças, são referentes aos impactos já existentes e aos que podem surgir, sendo as principais atividades causadoras de conflitos nas UCs brasileiras a agricultura e silvicultura, geralmente praticadas no interior das Unidades ou em suas ZAs, além de pastagem; caça e pesca ilegais; extração ilegal de madeira; extração mineral; coleta de produtos não madeireiros, como fibras e resinas; construção de infraestruturas, como estradas; escoamento de produtos de extrativismo ilegal; disposição inadequada de resíduos e rejeitos; introdução de espécies invasoras da fauna e da flora e incêndios provocados por ações antrópicas. Tais atividades são listadas em diversos trabalhos que avaliam os usos conflitantes existentes em UC's e seus entornos (FARIA; BARBOSA e SOARES NETO, 2019; MORAES; MELLO e TOPPA, 2015; OLIVEIRA e FARIA, 2019).

A partir desse contexto, ainda na quarta etapa, foi gerado o processamento dos conflitos existentes na área de estudo, de acordo com seu zoneamento, e como o PEAMP não apresenta uma proposta para sua ZA, apenas para os limites do parque, foi adotado para avaliação de conflitos na área de estudo o zoneamento proposto pela versão atualizada do PM da APAJoL, que corresponde, conforme mencionado anteriormente, à ZA do PEAMP. As categorias propostas pela STCP e SEMAD (2019) são: Zona de Preservação de Vida Silvestre (ZPVS); Zona de Proteção de Nascentes (ZPN); Zona de Conservação do Reservatório João Leite (ZCRJL); Zona de Uso Sustentável (ZUS); Zona de Uso Especial (ZUE); Zona de Adensamento Urbano (ZAU) e Núcleos Informais (NIs).

Cada uma das categorias citadas acima apresenta restrições e recomendações específicas, de acordo com seus objetivos, mas nesse trabalho puderam ser mapeados, com base na classificação do uso da terra para o ano de 2018, apenas os conflitos da ZPVS e ZCRJL, restritas a quase todas as classes, com exceção apenas da água e vegetação; a ZAU, onde há conflitos caso as APPs não estejam preservadas, e para os NIs, considerados como conflituosos, pois no momento não estão regularizados fundiária e ambientalmente pelas prefeituras municipais responsáveis. Levando esses aspectos em consideração, foi possível gerar o mapa de conflitos em relação ao zoneamento da APAJoL, por meio da intersecção entre as zonas propostas e o tipo de uso conflitante para 2018, considerando, inclusive, a malha viária que atravessa a ZCRJL.

Por fim, a quinta etapa foi de avaliação dos produtos cartográficos gerados, focando na identificação e análise dos conflitos de uso e cobertura da terra na ZA do PEAMP e em suas APPs, indicando as atividades conflitantes, em comparação aos objetivos propostos pela legislação e pelo PM da área em estudo. 
EM

\section{Uso da terra e cobertura vegetal na ZA do PEAMP}

Os mapas de uso da terra na ZA do PEAMP para 2002 e 2018 apontaram predominância de pastagem, embora tal categoria tenha sofrido um decréscimo de $16,13 \%$ nesse período (Figura 3). A agricultura é a terceira classe com maior representatividade, tendo um aumento de 5,44\% ao longo dos últimos dezesseis anos. A presença expressiva dessas atividades na região coincide com a vocação agropecuária do estado de Goiás, e a intensificação da agricultura nos últimos anos é uma consequência do processo de expansão da fronteira agrícola para áreas do Cerrado (SANTOS; NUNES e SANTOS, 2018).

Figura 3 - Uso da terra e cobertura vegetal da área de estudo.

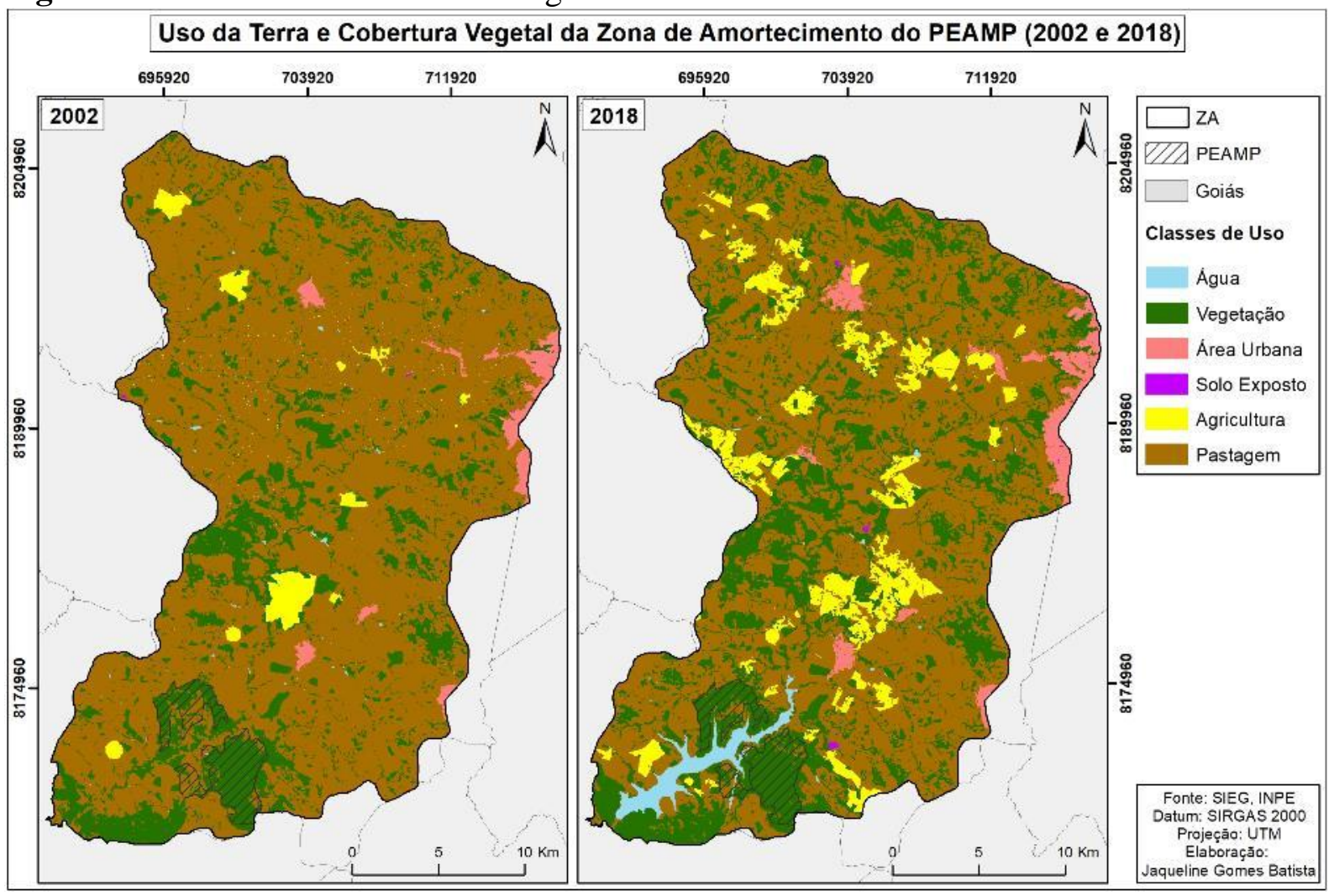

Fonte: Autoral.

Vale ressaltar que a predominância da pastagem deve estar relacionada principalmente às características do meio físico, pois grande parte das áreas ocupadas pela pecuária apresenta relevo mais acidentado, com declividade superior a $20 \%$, embora tenha solo relativamente fértil, enquanto a agricultura ocupa as áreas menos acidentadas, apesar da presença de Latossoslos Vermelho Ácricos, solos ácidos, que necessitam de correção.

A classe de água teve um aumento de $1,51 \%$, devido ao represamento do Ribeirão João Leite para construção do reservatório que, de acordo com a SEMARH e ITCO (2007), possuía vazão média de captação de $11,2 \mathrm{~m}^{3} / \mathrm{s}$, conforme dados de 1975 a 2006, apresentando forma alongada de $15 \mathrm{~km}$ de extensão e cerca de $800 \mathrm{~m}$ de largura média, com volume total de $129 \mathrm{hm}^{3}$, dos quais $117 \mathrm{hm}^{3}$ são de volume útil e $12 \mathrm{hm}^{3}$ de volume morto (PINA, 2013). Embora a licença para instalação do reservatório tenha sido emitida em 2001, possibilitando o início do desmatamento da área em 2002, apenas em 2009 as comportas da barragem foram fechadas para seu enchimento, até que em 2011 o reservatório atingiu sua cota, sendo concluída a etapa de preenchimento (MARTINS e SILVA, 2013). 
EM

As áreas urbanas correspondem à $4^{\mathrm{a}}$ classe mais representativa da ZA do PEAMP e, embora em 2002 equivalessem a apenas $1,74 \%$ da área total, apresentaram um aumento de 0,99\% em 2018, impulsionado pelo crescente desenvolvimento socioeconômico dessa região que, como mencionado anteriormente, abrange o eixo Goiânia-Anápolis, um dos mais importantes da região Centro-Oeste do país.

A classe menos significativa, de solo exposto, também teve acréscimo ao longo dos últimos anos, equivalendo a $0,2 \%$. Isso ocorreu devido à instalação de áreas de mineração, cujas lavras são a céu aberto, principalmente para extração de brita (SIC, 2009), sobre terrenos metamórficos correspondentes ao Complexo Granulítico Anápolis Itauçú Associação Ortogranulitos, onde predominam rochas metabásicas, e à Sequência Metavulcanossedimentar Silvânia, com presença predominante de xistos (MOREIRA et al., 2008).

Embora exista grande representatividade de atividades antrópicas, a classe de vegetação corresponde à segunda classe mais relevante da ZA do PEAMP, ocupando 27,18\% do território em 2018, após um acréscimo considerável de 8\%, desde 2002. Esse aumento foi uma consequência positiva da definição de limites para diversas UCs na região, tanto de uso sustentável, como a APAJoL, quanto de proteção integral, como o PEAMP e o PEJoL, indicando o cumprimento da função que exercem, possibilitando maior conservação dos remanescentes e recomposição vegetal na área de estudo em questão.

\section{Conflitos de uso da terra nas APPs de cursos de água da ZA do PEAMP}

Dentre as diretrizes da Política Nacional de Recursos Hídricos (BRASIL, 1997) encontra-se a necessidade de articulação entre a gestão dos recursos hídricos e a gestão do uso da terra, visando o uso múltiplo das águas e a priorização do atendimento às demandas para consumo humano e dessedentação de animais. Nesse contexto, as APPs são definidas pelo Código Florestal (BRASIL, 2012) como "área protegida, coberta ou não por vegetação nativa, com a função ambiental de preservar os recursos hídricos, a paisagem, a estabilidade geológica, a biodiversidade, facilitar o fluxo gênico de fauna e flora, proteger o solo e assegurar o bem-estar das populações humanas", apresentando grande relevância no que tange à conservação dos recursos naturais e qualidade ambiental do meio, especialmente da hidrosfera.

Nesse sentido, as APPs de canais de drenagem apresentarão correspondência com as áreas de matas de galeria ou matas ciliares, que ocorrem contínuas e adjacentes ao longo do comprimento do curso de água, mas têm sua largura dependente de fatores como a topografia do terreno, responsável também por determinar a dinâmica hídrica do solo e suas condições de drenagem. Sendo assim, as propriedades edáficas sob as matas de galeria variam ao longo do curso hídrico, influenciando na morfologia e composição espacial, e sua vegetação nativa desempenha funções fundamentais para a conservação da água e do solo (EMBRAPA, 2001).

Diante das questões apresentadas acima sobre a relevância das APPs na manutenção da qualidade ecossistêmica, tendo em vista a captação dos recursos hídricos da BHRJL para abastecimento público e utilizando como base a legislação vigente, tomou-se como fundamental neste trabalho a análise dos conflitos de uso da terra nas APPs de nascentes, de canais de drenagem e do reservatório do Ribeirão João Leite, situados dentro da ZA do PEAMP, que correspondem, de acordo com o mapeamento realizado, a 6,88\% da área de estudo para 2002 e a 9,05\% para 2018, cujo aumento se deve à instalação do reservatório.

Conforme apresentado por Kreitlow et al. (2016) os conflitos de uso da terra ocorrem mediante a ocupação por atividades antrópicas de locais que não são recomendados devido às 
EM

limitações ambientais, relevância ambiental para conservação dos recursos naturais, ou incompatibilidades jurídicas. Avaliando-se os conflitos de uso da terra nas APPs de cursos de água na ZA do PEAMP (Figura 4), do total da área destinada às APPs, em 2002, 75,28\% estavam ocupadas por pastagens, classe predominante na área de estudo. Esse tipo de uso antrópico presente nas faixas marginais aos cursos hídricos implica no risco de contaminação hídrica e ainda de compactação do solo, pelo acesso e pisoteio do gado a tais locais. Vale ressaltar que a compactação pode diminuir significativamente as taxas de infiltração de água pluvial em determinadas regiões, possibilitando a instalação de processos erosivos, assoreamentos e intensificação das inundações dos canais de drenagem (SOUZA et al., 2012).

Figura 4 - Conflitos de uso nas APPs dos cursos hídricos da área de estudo para 2002.

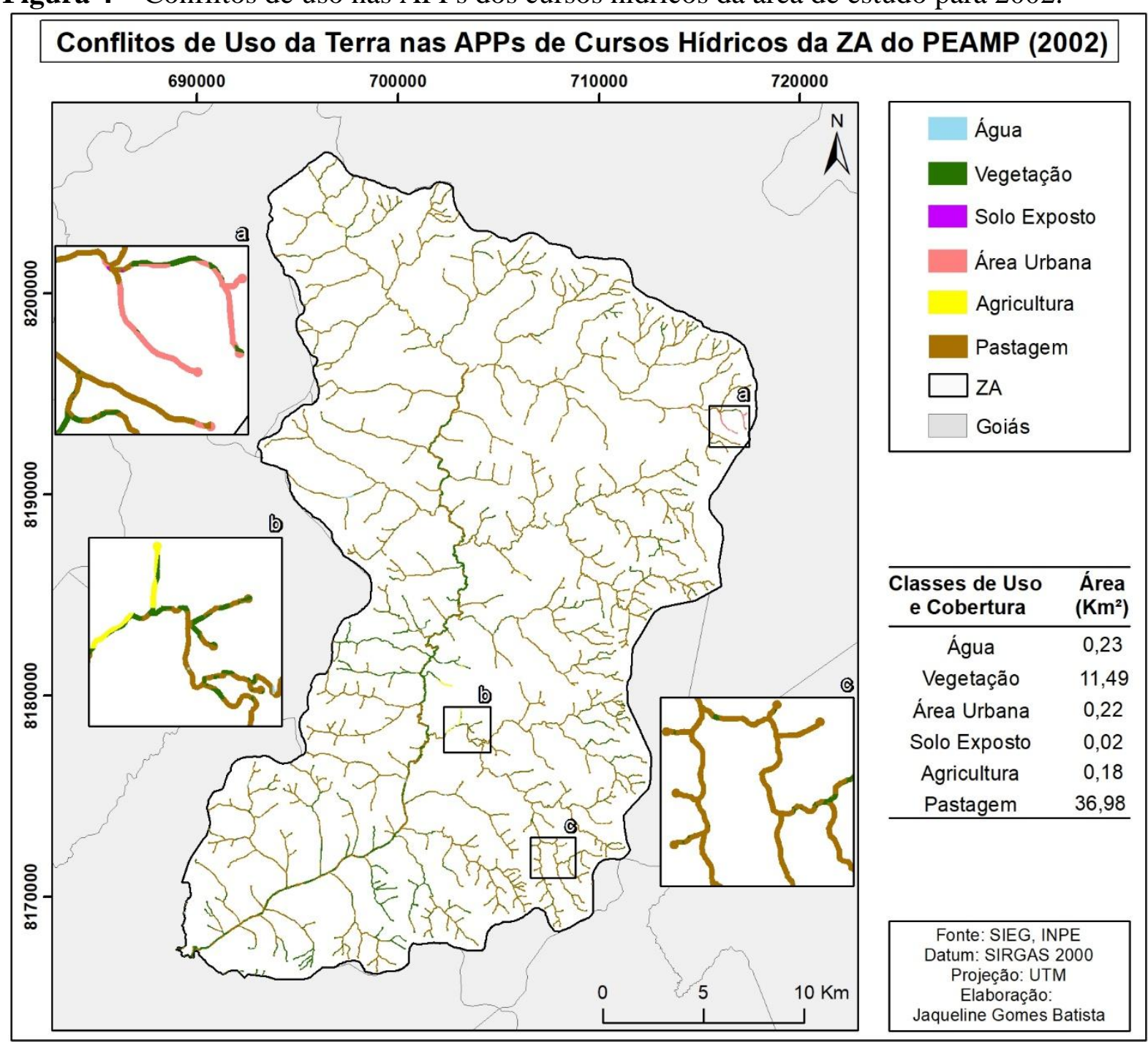

Fonte: Autoral.

Das demais categorias, além da pastagem, apenas a vegetação apresenta uma área significativa, ocupando 23,39\% das APPs, predominantemente na região sul da ZA e na faixa marginal do Ribeirão João Leite, principal canal de drenagem da área de estudo, e seu reservatório. Embora a vegetação seja a segunda classe mais representativa, e cada uma das demais categorias de uso antrópico ocupem menos de $1 \%$ das APPs, os dados obtidos não são satisfatórios, pois indicam que mais da metade das faixas marginais dos recursos hídricos estava sendo utilizada para desenvolvimento de atividades inadequadas, ou seja, conflituosas. 
EM

Por outro lado, para o ano de 2018 (Figura 5), é possível visualizar uma mudança positiva, pois as áreas de vegetação se tornaram mais expressivas do que de pastagem, ocupando 42,07\% das APPs, enquanto a classe anteriormente predominante teve suas áreas reduzidas para 39,49\%. Houve também um aumento significativo da presença da classe de água, a partir da implantação do reservatório, que passou a ocupar 17,21\% das faixas marginais dos recursos hídricos. Além disso, assim como a pastagem, que teve sua área reduzida, as demais categorias conflitantes também sofreram redução, mesmo que inexpressiva, com exceção da agricultura, que passou a ocupar 0,61\% das APPs.

Figura 5 - Conflitos de uso nas APPs dos cursos hídricos da área de estudo para 2018.

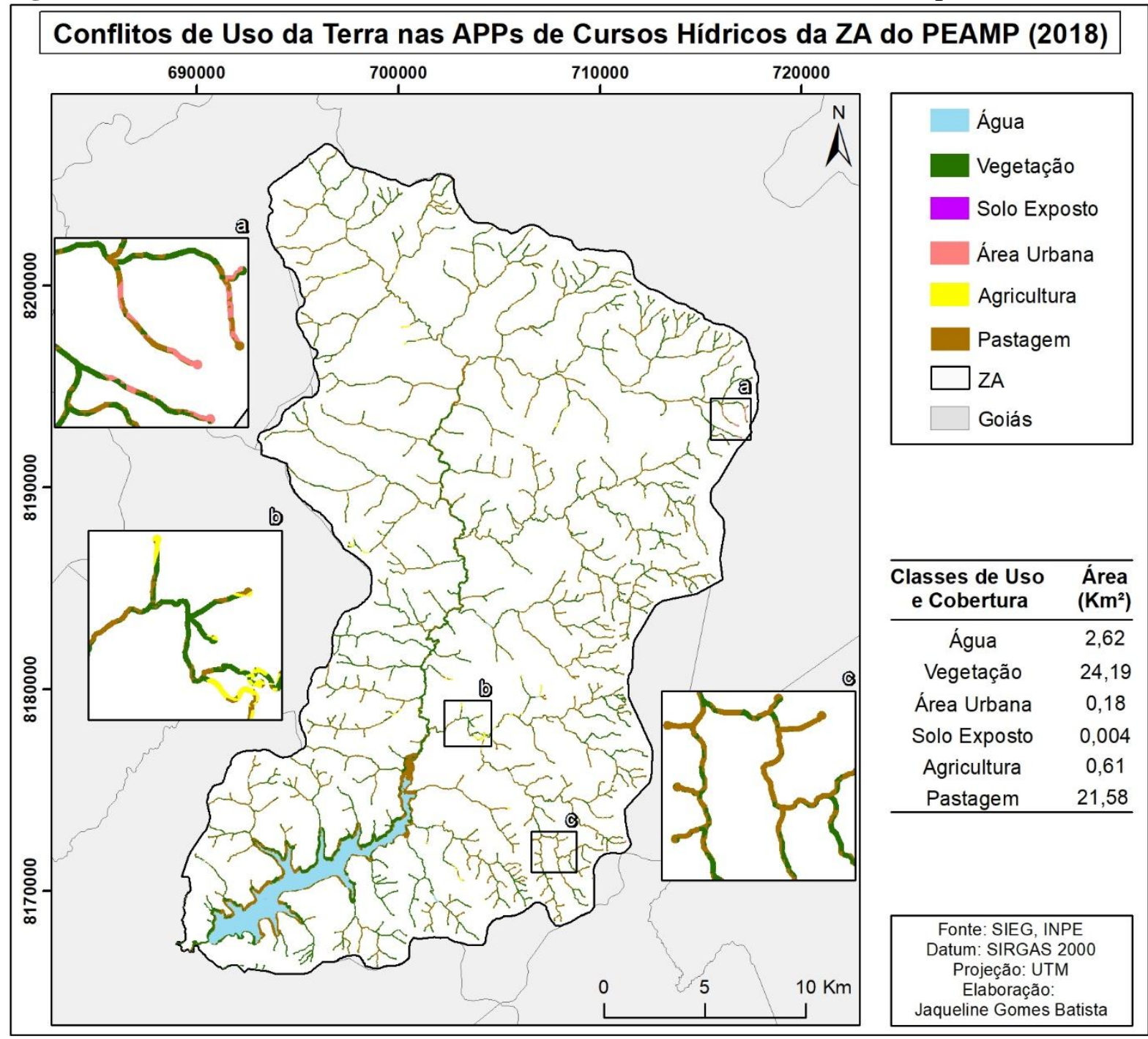

Fonte: Autoral.

As classes de água, área urbana, solo exposto e agricultura foram correspondentes à parcela menos representativa nas APPs para os dois períodos, de acordo com os dados expostos acima, sendo que, para ambos os anos, é possível afirmar que o único local em que as áreas urbanas se tornaram conflitantes foi dentro dos limites municipais de Anápolis. Já a classe de água apenas se tornou expressiva no mapa de 2018, devido à instalação do reservatório do Ribeirão João Leite.

Apesar de serem mantidos alguns padrões, os mapas acima também indicaram resultados distintos entre si: em 2002 as áreas conflituosas com APPs equivaliam a cerca de 
EM

$5,24 \%$ da área da ZA e a 76,14\% de suas APPs, enquanto as não conflitantes, correspondentes somente às classes de vegetação e água, ocupavam apenas $1,64 \%$ da área de estudo e $23,86 \%$ das faixas marginais dos cursos hídricos. Já para 2018, as áreas de conflito correspondiam a $3,69 \%$ da ZA e a 40,72\% das APPs, enquanto as áreas não conflitantes correspondiam a $5,37 \%$ da ZA e a 59,28\% das margens dos canais de drenagem.

Esses resultados indicaram que o ano de 2018 apresentou avanços na conservação das APPs, tendo em vista que a vegetação passou a ocupar $42,07 \%$ das margens da rede hidrográfica. Embora ainda não seja o resultado ideal, pois essas zonas deveriam ser totalmente preservadas e cobertas por vegetação, ou água, isso reforça a constatação feita a partir da análise do uso da terra anteriormente, de que a implantação de três UCs nessa região influenciou positivamente na conservação e recuperação da vegetação, por meio do aumento da cobertura vegetal em diversas áreas do parque e em seu entorno e, consequentemente, nas APPs.

Outra constatação realizada foi de que os reflexos da expansão da fronteira agropecuária e da urbanização no Cerrado também atingiram o PEAMP e seu entorno, por meio da instalação acelerada de atividades como o desmatamento; crescente desenvolvimento da agricultura; represamento de cursos hídricos; construção de barragens; extração mineral; pisoteio excessivo de animais e acelerado processo de urbanização, citadas como as mais impactantes nas áreas desse bioma por Fernandes e Pessôa (2011) e Latrubesse et al. (2019), causando danos diversos e intensificando, ou promovendo novos conflitos.

Também foi possível observar que há consonância entre os resultados desse trabalho e demais pesquisas realizadas na região, como o de Santos; Nunes e Santos (2018), que analisou uma faixa de $3 \mathrm{~km}$ no entorno do Reservatório do João Leite, indicando presença expressiva de pastagens, que ocupavam $27,27 \%$ da área analisada, e predominância de vegetação, que equivalia a 43,24\%. Os autores constataram, ainda, que mais de $70 \%$ das APPs da área de estudo apresentavam uso devido, um valor que se aproxima do obtido no presente trabalho, que indicou que aproximadamente $60 \%$ das APPs da ZA do PEAMP possuiam uso adequado, ou seja, estavam preservadas.

Outros trabalhos de conflitos em APPs de canais de drenagem do Estado de Goiás, como o de Santos et al. (2019) e Santos (2019) também indicam resultados semelhantes ao do presente estudo, no qual o primeiro constata que 47,87\% das APP's do Rio Caldas são conflituosas estando pouco mais de $50 \%$ preservadas, e o segundo aponta que quase todos os municípios da Região Metropolitana de Goiânia, com exceção de Hidrolândia e Bela Vista de Goiás, apresentam mais de $40 \%$ de suas APP's degradadas.

\section{Conflitos de uso da terra na ZA do PEAMP}

A avaliação dos conflitos para toda a ZA do PEAMP foi realizada, conforme indicado na metodologia, a partir da proposta do PM da APAJoL, que a divide em sete zonas, de acordo com suas diferentes características ambientais e socioeconômicas, das quais a que apresenta maior representatividade é a ZUS, ocupando 47\% do total da área de estudo. Das zonas que puderam ser avaliadas, em relação aos conflitos, com base na classificação do uso da terra para 2018, a mais representativa é a ZPVS, que além de abrigar os maiores remanescentes de Cerrado da ZA, cerca toda a área da ZCRJL, enquanto os NIs corresponderam à menor porção, com menos de $1 \%$.

O mapeamento das áreas conflitantes, de acordo com o zoneamento proposto para a APAJoL, indica que a maior parte das irregularidades se encontra na ZPVS (Figura 6), equivalentes a 1,98\% de toda a ZA. Essa zona equivale ao PEAMP e ao PEJoL, UCs de 
EM

QUESTÃO

V.13 N. $03 \bullet 2020$

pág. 51-70

proteção integral nas quais somente são permitidas a realização de pesquisas científicas, desenvolvimento de atividades de educação ambiental e práticas de turismo ecológico (BRASIL, 2010). Embora fosse esperado que o maior percentual de conflitos se encontrasse nessa área, diante de suas extremas restrições e da elevada pressão que sofre, tal resultado foi considerado significativamente negativo, por ocupar cerca de $30 \%$ do total dessa zona, que deveria apresentar o máximo de áreas vegetadas e recursos hídricos preservados.

Figura 6 - Conflitos de uso da terra em relação ao zoneamento da área de estudo - 2018.

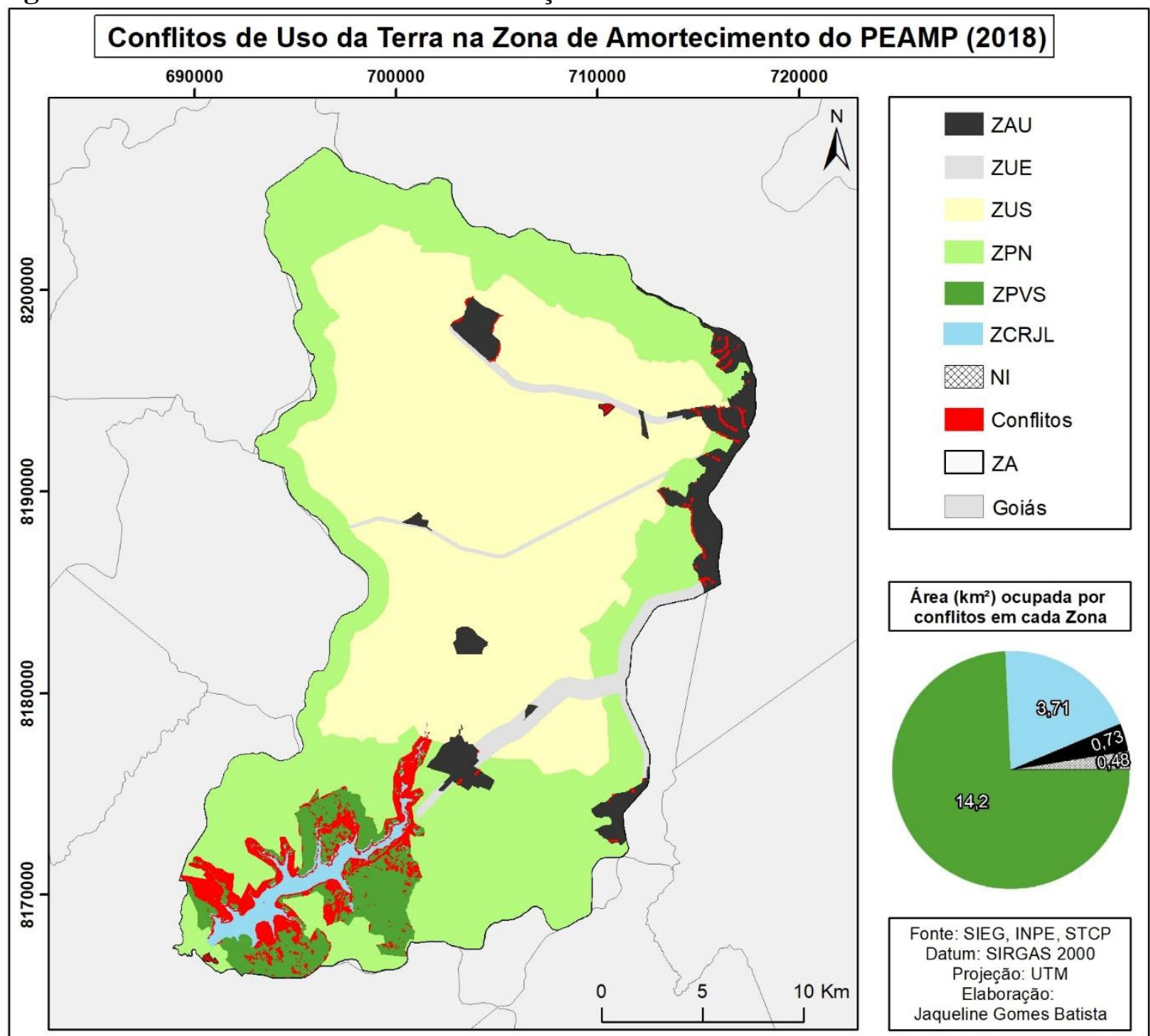

Fonte: Autoral.

A segunda zona com maior presença de conflitos foi a ZCRJL, correspondendo a $0,52 \%$ de toda a ZA do PEAMP e a $24,44 \%$ de seus $15,32 \mathrm{~km}^{2}$. Para o mapeamento dos conflitos dessa zona foram consideradas, conforme mencionado anteriormente, todas as áreas sem cobertura vegetal, ou água, e ainda a malha viária que a sobrepõe, correspondente à rodovia GO-060/BR-153. A existência dessa rodovia sobre a ZCRJL em determinados trechos ameaça a qualidade da água do reservatório, em função do risco de acidentes envolvendo veículos com cargas caracterizadas como perigosas ou contaminantes, além da qualidade ecossistêmica do parque, uma vez que a UC é dividida pela estrada, caracterizando processo de fragmentação antrópica, que compromete o tráfego da fauna entre os fragmentos florestais (REZZADORI; HARTMANN e HARTMANN, 2016). 
EM

Os conflitos existentes na ZAU, que são diretamente vinculados à qualidade ambiental das APPs de cursos hídricos da área de estudo, ocupavam apenas 2,19\% de sua área total, o que corresponde a $0,1 \%$ da ZA do PEAMP (Tabela 1). Isso indica que as governanças municipais têm atuado de forma relativamente eficaz na preservação de seus canais de drenagem, mas que ainda é necessária maior atenção para que haja total recuperação das áreas degradadas. Por outro lado, a zona de NIs precisa de adequação imediatamente, mesmo que corresponda a apenas $0,07 \%$ da ZA do PEAMP, tendo em vista que suas áreas são integralmente conflituosas. É composta por dois núcleos distintos, o Condomínio Mansões do Lago, localizado em Anápolis, e a Estância Serrania, situada dentro dos limites municipais de Goiânia, áreas que devem ser mantidas imutáveis pelos órgãos municipais responsáveis, até que sejam feitas suas regularizações fundiárias e ambientais.

Tabela 1 - Zonas definidas para a APAJoL e suas áreas conflitantes, em $\mathrm{km}^{2}$ e porcentagem.

\begin{tabular}{ccccc}
\hline Zonas & Área $\left(\mathbf{K m}^{\mathbf{2}}\right)$ & $\begin{array}{c}\text { \% em relação à } \\
\mathbf{Z A}\end{array}$ & $\begin{array}{c}\text { Área conflitante } \\
\left(\mathbf{K m}^{2}\right)\end{array}$ & $\begin{array}{c}\text { \% conflitante em } \\
\text { relação à ZA }\end{array}$ \\
\hline ZPVS & 49,55 & 6,94 & 14,2 & 1,98 \\
ZPN & 258,35 & 36,20 & - & - \\
ZCRJL & 15,32 & 2,15 & 3,71 & 0,52 \\
ZUS & 332,46 & 46,59 & - & - \\
ZUE & 24,01 & 24,01 & - & - \\
ZAU & 33,4 & 4,68 & 0,73 & 0,1 \\
NI & 0,48 & 0,07 & 0,48 & 0,07 \\
\hline Total & 713,57 & 100 & 19,2 & 2,67 \\
\hline
\end{tabular}

Fonte: Adaptado de STCP Engenharia de Projetos Ltda. (2019).

Embora tenha sido possível avaliar uma parte considerável dos conflitos existentes na ZA do PEAMP por meio do levantamento dos seus tipos de uso, utilizando técnicas de sensoriamento remoto, e que esses tenham totalizado apenas $2,67 \%$ da área de estudo, mais de $50 \%$ da ZA não foi contemplada por essa técnica, devido à ausência e inacessibilidade aos dados quantitativos e qualitativos referentes aos tipos de empreendimento, atividades e imóveis presentes na região. Ainda assim, com base em estudos como o realizado por Oliveira (2018), sabe-se que entre 1985 e 2017 houve um aumento de 6\% nos índices de queimada em uma faixa de $10 \mathrm{~km}$ do entorno do PEAMP e do PEJoL, sendo que mais de 50\% da área onde se encontram os remanescentes dessas UCs estão sob risco entre médio e alto de incêndio (Tabela 2).

Tabela 2 - Percentual de risco a incêndios do PEAMP, PEJoL e seu entorno.

\begin{tabular}{ccc}
\hline Risco de Incêndio & $\begin{array}{c}\text { Área do PEAMP e PEJoL } \\
(\boldsymbol{\%})\end{array}$ & $\begin{array}{c}\text { Área do entorno dos remanescentes } \\
\text { florestais }(\boldsymbol{\%})\end{array}$ \\
\hline Baixo & 13 & 27,8 \\
Médio & 35 & 36,1 \\
Alto & 52 & 36 \\
\hline
\end{tabular}

Fonte: Adaptado de Oliveira (2018).

Além do estudo citado acima, Santos; Nunes e Santos (2018) mapearam fatores de degradação como pivôs de irrigação, lixão, empreendimentos mineiros e diversos focos de queimada dentro da área que corresponde à ZCRJL, ZPN e ZPVS, indicando conflitos de acordo com as recomendações existentes para essas zonas. Sendo assim, considera-se que o presente trabalho disponibiliza uma boa base, mas que são necessários novos estudos mais aprofundados e novos esforços do governo, para que sejam obtidos os percentuais precisos de 
EM

QUESTÃO

V.13 N. $03 \bullet 2020$

pág. 51-70

usos indevidos dentro da ZA do PEAMP, subsidiando maior eficácia para o planejamento e recuperação de áreas degradadas nessa região.

\section{Considerações finais}

A ZA do PEAMP, proposta pelo PM do parque, foi considerada pelo presente estudo como uma escolha adequada, por se tratar de uma área com grande relevância para a conservação dos recursos naturais do Bioma Cerrado no Estado de Goiás, tendo em vista que corresponde a boa parte do território da BHRJL, que abriga recursos hídricos e remanescentes de vegetação de grande valor ambiental e socioeconômico, mas é conhecida por ser uma área utilizada de forma intensiva há décadas, para o desenvolvimento de atividades antrópicas, predominantemente agropastoris.

Com base nos resultados apresentados, foi possível observar que os conflitos mapeados, seja nas APPs, seja em toda a ZA, se instalaram predominantemente nas regiões menos declivosas da área de estudo, principalmente nas proximidades de canais de drenagem, inclusive do próprio Reservatório do Ribeirão João Leite. Essa constatação vai ao encontro da afirmação feita no início do presente estudo, de que a riqueza de recursos naturais presente nas UCs, sejam elas de proteção integral ou de uso sustentável, é um dos principais propulsores para o surgimento de conflitos.

Embora tenham sido constatados conflitos, como desenvolvimento de pastagem, agricultura e adensamento urbano em locais inapropriados, de acordo com o zoneamento da APAJoL e do PEAMP, apenas tendo acesso aos dados de fiscalização ou a partir da realização de campos e análises de amostras de solo e água seria possível mensurar o quão impactantes esses conflitos são, já que os levantamentos foram todos feitos via imagens de satélite e não nos permitiu mensurar os danos causados, por exemplo, pelo uso de agrotóxicos nas proximidades do reservatório, ou contaminação e degradação dos demais recursos hídricos e dos solos.

Por fim, mesmo com a constatação da existência de conflitos de uso da terra na ZA do PEAMP e em suas APPs de corpos hídricos, um dos pontos mais importantes da pesquisa foi a observação do aumento expressivo das áreas de vegetação no ano de 2018, que permite concluir que a criação das UCs nessa região, a partir do ano de 1992, foi uma forma eficaz de promover a conservação e recuperação de determinadas áreas.

\section{Referências}

BRASIL. Lei n ${ }^{\circ}$ 9.433, de 08 de janeiro de 1997 - Política Nacional de Recursos Hídricos. Brasília - $\quad$ DF, $1997 . \quad$ Disponível em: http://www.planalto.gov.br/ccivil_03/LEIS/L9433.htm>. Acesso em: 10/2018.

BRASIL. Lei $\mathbf{N}^{0}$ 9.985, De 18 De Julho De 2000 - Sistema Nacional de Unidades de Conservação. Brasília - $\quad$ DF, 2000. Disponível em: < http://www.planalto.gov.br/ccivil_03/leis/L9985.htm>. Acesso em: 12/2019.

BRASIL. Lei $\mathbf{n}^{\circ} \mathbf{1 2 . 6 5 1}$, de 25 de maio de 2012 - Lei da Proteção da Vegetação Nativa. Brasília - DF, 2012. Disponível em: <http://www.planalto.gov.br/ccivil_03/_Ato20112014/2012/Lei/L12651.htm>. Acesso em: 12/2019. 
EM

CHAVEIRO, E. F.; BARREIRA, C. C. M. A. Cartografia de um pensamento de Cerrado. In: Cerrados: Perspectivas e Olhares. In: PELÁ, M.; CASTILHO, D. Cerrados: perspectivas e olhares. Goiânia: Editora Vieira, 2010. p. 15-33.

COELHO, L. M. C. Indicadores de Impactos Ambientais na Bacia do Ribeirão João Leite/GO: Implicações Ambientais e na Saúde. Dissertação de Mestrado - Pontifícia Universidade Católica, Departamento de Ciências da Saúde, Programa de Pós-Graduação em Ciências Ambientais e Saúde, Goiânia, 2011. Disponível em: < http://tede2.pucgoias.edu.br:8080/handle/tede/2905 >. Acesso em: 05/2018.

DIAS, J. M.; PEREIRA, N. M. Considerações sobre a evolução do Sistema Nacional de Unidades de Conservação e o ordenamento territorial da Amazônia: interações entre o Estado e a Ciência. Revista Desenvolvimento e Meio Ambiente. Curitiba - PR, n.21, p. 69-88, 2010. Disponível em: < https://revistas.ufpr.br/made/article/view/15933>. Acesso em: $12 / 2019$.

DIEGUES, A. C. O Mito Moderno da Natureza Intocada. São Paulo: Editora Hucitec. $6^{\circ}$ ed., 2008. Disponível para download em: < http://nupaub.fflch.usp.br/sites/nupaub.fflch.usp.br/files/O\%20mito\%20moderno.compressed. pdf>. Acesso em: 12/2019.

DIEGUES, A. C. Conhecimentos, práticas tradicionais e a etnoconservação da natureza. Revista Desenvolvimento e Meio Ambiente. Curitiba - PR, v.50, p. 116-126, 2019. Disponível em: 〈https://revistas.ufpr.br/made/article/view/66617〉. Acesso em: 12/2019.

EMBRAPA - EMPRESA BRASILEIRA DE PESQUISA AGROPECUÁRIA. Cerrado: Caracterização e Recuperação de Matas de Galeria. Planaltina - DF, 2001.

FARIA, K. M. S. de; BARBOSA, R. M.; SOARES NETO, G. B. Conflitos de Uso em Unidades de Conservação: Análise Histórica da Degradação Ambiental da Serra das Areias, Goiás, Brasil. Revista Geoambiente On-line. Jataí - GO, n.33, 2019.

FERNANDES, P. A.; PESSÔA, V. L. S. O Cerrado e suas Atividades Impactantes: Uma leitura sobre o Garimpo, a Mineração e a Agricultura Mecanizada. Revista Observatorium. Uberlândia - MG, v.3, n.7, p. 19-37, 2011.

GOMES, L. J.; CARMO, M. S. do; SANTOS, R. F. dos. Conflitos de Interesse em Unidades de Conservação do Município de Parati, Estado do Rio de Janeiro. Revista Informações Econômicas. São Paulo - SP, n.6, v.34, 2004. Disponível em: < http://www.pagem.uerj.br/textos/172_2009/docs/news/CONFLITOS\%20DE\%20INTERESS ES\%20EM\%20UNIDADES\%20DE\%20CONSERVA\%C7\%20\%C3O.pdf >. Acesso em: $12 / 2019$.

IBGE - Instituto Brasileiro de Geografia e Estatística. Mapa de Biomas do Brasil 1:5.000.000. Rio de Janeiro, 2004. Disponível em: <https://www.ibge.gov.br/geociencias/informacoes-ambientais/15842biomas.html?edicao=16060\&t=acesso-ao-produto $>$. Acesso em: 12/2019. 
EM

INPE - Instituto Nacional de Pesquisa Espaciais. Catálogo de Imagens. Brasil, 2018. Disponível em: < http://www.dgi.inpe.br/CDSR/>. Acesso em: 09/2018.

KREITLOW, J. P.; SILVA, J. S. V.; NEVES, S. M. A. S.; NEVES, R. J.; NEVES, L. F. S. Vulnerabilidade ambiental e conflito no uso da terra no município de Mirassol D'Oeste, Brasil. Revista Brasileira de Cartografia. Uberlândia - MG, v. 68, n. 10, p. 1917-1936, 2016. Disponível em: <https://ainfo.cnptia.embrapa.br/digital/bitstream/item/162867/1/APVulnerabilidade-JVila-2006.pdf>. Acesso em: 12/2019.

LATRUBESSE, E. M.; ARIMA, E.; FERREIRA, M. E.; NOGUEIRA, S. H.; WITTMANN, F.; DIAS, M. S.; DAGOSTA, F. C. P.; BAYER, M. Fostering Water Resource Governance and Conservation in the Brazilian Cerrado Biome. Conservation Science and Practice Journal. Washington - DC, e. 17, 2019.

LATRUBESSE, E. M.; CARVAlHO, T. M. de. Geomorfologia do Estado de Goiás e Distrito Federal. Goiânia - GO, 2006. Disponível para download em: < http://www.sieg.go.gov.br/downloads/Livro_geomorfologia.pdf>. Acesso em: 10/2018.

MARTINS, M. A. N.; SILVA, M. M. A Construção da Barragem João Leite e Os Reflexos nas Áreas de Abrangência do Reservatório. Anais IV ConGea. Salvador - BA, 2013. Disponível em: < https://www.ibeas.org.br/congresso/Trabalhos2013/VII-038.pdf>. Acesso em: 11/2018.

MMA - Ministério do Meio Ambiente. Conflitos: Estratégias de Enfrentamento e Mediação. Brasília - $\quad$ DF, 2015. Disponível em: < http://ava.icmbio.gov.br/pluginfile.php/108/mod_data/content/2034/caderno4.pdf >. Acesso em: 10/2018.

MMA - Ministério do Meio Ambiente. O Bioma Cerrado. Brasil. Disponível em: < https://www.mma.gov.br/biomas/cerrado > . Brasil, 2018. Acesso em: 05/2018.

MORAES, M. C. P. de; MELLO, K. de; TOPPA, R. H. Análise da Paisagem de uma Zona de Amortecimento como Subsídio para o Planejamento e Gestão de Unidades de Conservação. Revista Árvore. Viçosa - MG, v. 39, n.1, p.1-8, 2015.

MOREIRA, M. L. O.; MORETON, L. C.; ARAÚJO, V. A. de; LACERDA FILHO, J. V. de; COSTA, H. F. de. Geologia do Estado de Goiás e Distrito Federal. Goiânia: CPRM/SIC, 2008. Disponível para download em: http://rigeo.cprm.gov.br/xmlui/handle/doc/10512?show=full>. Acesso em: 10/2018.

OLIVEIRA, T. B. Aplicação da Dendrocronologia na Identificação de Processos Erosivos e Incêndios Florestais nos Parques Estaduais Altamiro de Moura Pacheco e João Leite, Goiânia, Goiás, Brasil. Dissertação de Mestrado - Universidade Federal de Goiás, Programa de Pós-Graduação em Ciências Ambientais, Goiânia, 2018.

OLIVEIRA, R. B. de; FARIA, K. M. S. de. Análise do Conflito Potencial de Uso da Terra na Microrregião Chapada dos Veadeiros (GO): Cobertura e Uso versus Aptidão Agrícola. Revista Elisée. Porangatu - GO, v. 8, n.1, 2019. 
EM

PINA, R. W. de. Avaliação Experimental do Crescimento da Comunidade Fitoplanctônica do Reservatório João Leite em Diferentes Condições de Luz e Nutrientes. Dissertação de Mestrado - Universidade Federal de Goiás, Programa de PósGraduação em Engenharia do Meio Ambiente, Goiânia, 2013. Disponível em: < https://repositorio.bc.ufg.br/tede/handle/tede/3804>. Acesso em: 10/2018.

PORTAL TERRABRASILIS. Incrementos de Desmatamento Acumulado por Ano Cerrado - Estados. Brasil, 2019. Disponível em: $\langle$ http://terrabrasilis.dpi.inpe.br/app/dashboard/deforestation/biomes/cerrado/increments $>$.

Acesso em: 12/2019.

PRIMACK, R. B.; RODRIGUES, E. Biologia da Conservação. Londrina: Editora Planta, 2001. Disponível em: <https://pt.slideshare.net/Santa1304/biologia-da-conservao-primackamp-rodrigues $>$. Acesso em: 12/2019.

REZZADORI, T.; HARTMANN, M. T.; HARTMANN, P. A. Proximidade de Rodovias pode Influenciar a Fragmentação Florestal? Um Estudo de Caso no Norte do Rio Grande do Sul. Revista Biotemas. Florianópolis - SC, v. 29, n. 3, p. 21-29, 2016. Disponível em: <https://periodicos.ufsc.br/index.php/biotemas/article/view/2175-925.2016v29n3p21/32282>. Acesso em: 12/2019.

RIBEIRO, R. J. C.; BAPTISTA, G. M. M.; BIAS, E. S. Comparação dos métodos de classificação supervisionada de imagem Máxima Verossimilhança e Redes Neurais em ambiente urbano. Anais XIII SBSR, Florianópolis, 2007, p. 5471-5478. Disponível em: <http://marte.sid.inpe.br/col/dpi.inpe.br/sbsr@80/2006/10.03.11.59/doc/5471-5478.pdf>.

Acesso em: 12/2019.

SANTOS, S. A. dos; NUNES, F. G.; SANTOS, A. M. dos. Intensidade dos Processos Antropogênicos no Entorno do Reservatório do Ribeirão João Leite - Goiás - Brasil. Revista do Departamento de Geografia. São Paulo - SP, v. 36, 2018.

SANTOS, L. A. C.; VIEIRA, L. M. F.; MARTINS, P. T. A.; FERREIRA, A. A. Conflitos de Uso e Cobertura do Solo para o Período de 1985 a 2017 na Bacia Hidrográfica do Rio Caldas - GO. Revista Fronteiras. Anápolis - GO, v.8, n.2, 2019.

SANTOS, J. B. dos. Áreas de Preservação Permanente como Instrumentos para Conservação dos Recursos Hídricos: Estudo de Caso na Região Metropolitana de Goiânia, Goiás. Tese de Doutorado - Universidade Federal de Goiás, Instituto de Estudos Socioambientais (IESA), Programa de Pós-Graduação em Geografia, Goiânia, 2019.

SEMAD - Secretaria de Estado de Meio Ambiente e Desenvolvimento Sustentável. Parque Estadual Altamiro de Moura Pacheco - PEAMP. 2018. Disponível em: $<$ http://www.meioambiente.go.gov.br/component/content/article/118-meioambiente/unidades-de-conserva\%C3\% A7\%C3\% A3o/1110-parque-estadual-altamiro-demoura-pacheco-peamp.html?Itemid=101>. Acesso em: 12/2019.

SEMARH - Secretaria do Meio Ambiente e dos Recursos Hídricos; ITCO - Instituto de Desenvolvimento Tecnológico do Centro Oeste. Parque Estadual Altamiro de Moura Pacheco - PEAMP - Plano de Manejo. Goiânia, Goiás, 2008. Versão Digital. 
EM

SEMARH - Secretaria do Meio Ambiente e Dos Recursos Hídricos; ITCO - Instituto de Desenvolvimento Tecnológico do Centro Oeste. Área de Proteção Ambiental João Leite APA João Leite - Plano de Manejo. Goiânia - GO, 2007. Disponível em: < http://www.sgc.goias.gov.br/upload/arquivos/2015-09/plano-de-manejo-apa-joao-leite.pdf $>$. Acesso em: 10/2018.

SIC - Secretaria de Estado de Indústria, Comércio e Serviços. Empreendimentos mineiros. Goiânia $\quad-\quad$ GO, 2009. $\quad$ Disponível $\quad$ em:< http://www.sieg.go.gov.br/produtosIMB.asp?cod=2355>. Acesso em: 12/2019.

SOUZA, S. R. de; MACIEL, M. N. M.; OLIVEIRA, F. A.; JESUÍNO, S. A. Caracterização do Conflito de Uso e Ocupação do Solo nas Áreas de Preservação Permanente do Rio Apeú, Nordeste do Pará. Revista Floresta. Curitiba - PR, v. 42, n. 4. p. 701-710, 2012.

STCP - Engenharia de Projetos Ltda.; SEMAD - Secretaria de Estado de Meio Ambiente e Desenvolvimento Sustentável. Plano de Manejo - Área de Proteção Ambiental João Leite. Goiânia $\quad-\quad$ GO, $2019 . \quad$ Disponível em: <http://www.meioambiente.go.gov.br/files/Apa_JoaoLeite/Plano_Manejo.pdf $>$. Aceso em: $12 / 2019$. 